Alexandru MATEI

Faculty of Letters, "Transilvania” University

Braşov, Romania

alexandru.matei@unitbv.ro

\title{
MICHEL SERRES'S INTEGUMENTUM, OR WHY ECOLOGY LIES (ALSO) BEYOND ARGUMENTS
}

\begin{abstract}
Given the secular domination of science and the aspiration of various particular ideologies to gain recognition as "scientific truths", entering the sphere of emancipated humanity (as the "modern world" presents itself), the frontier between scientific and non-scientific is increasingly passing through the interior of science itself ${ }^{1}$.

- Mihai Dinu Gheorghiu, Scena literaturii, Elemente pentru o sociologie a culturii românești, 1987.
\end{abstract}

Recommended Citation: Matei, Alexandru. "Michel Serres's Integumentum, or Why Ecology Lies (Also) Beyond Arguments." Metacritic Journal for Comparative Studies and Theory 7.1 (2021): https://doi.org/10.24193/mjcst.2021.11.04

\begin{abstract}
During the Middle Ages, integumentum was a term widely used by "intellectuals" (Le Goff) in order to unfold the function of allegory: there is no story whose signification does not echo the sacred texts, and every sacred truth needs a story to bring it to life. Integumentum was a way to make this echo explicit: a sort of "poetical coat hiding a moral or philosophical truth" (John of Garland). We want to suggest that, while no one uses integumentum anymore in order to designate the rhetoric of modern and contemporary theoretical discourse, it is in ecological theory that we may rediscover its afterlives. Hence, integumentum is not only a form of telling truths, but a form of memory, as well. In this respect, Michel Serres may be considered the first "ecological" thinker, as he avoids abstract metalanguages as much as possible, relying instead on fictions and characters in his attempt to describe the world afresh. If integumentum resurfaces as the proper way of "ecologizing," instead of modernizing
\end{abstract}

\footnotetext{
${ }^{1}$ All translations from Romanian and French are mine.
} 
(Latour), we would like to uncover, in Michel Serres's works, the dialectic of subjects and objects.

Key words: Michel Serres, integumentum, ecological thought, Bruno Latour, rhetoric.

The starting point of this text is a hypothesis easy to understand if only by following Michel Foucault's model of analysis in Les Mots et les choses. Une archéologie des sciences humaines (French ed. 1966, English ed. 1989, The Order of Things. An Archeology of Human Sciences). If all discourses of knowledge have their own historicity insinuated into their enunciations, then, at a certain point, what is said under the name of literary theory for instance can no longer account for what, under the same name, was said before. It is this essential oversight that Michel Serres's work seeks to recall, and consequently to eliminate from the broad field of knowledge. I will devote the first part of this text to retracing the path of this oblivion and to indicating the gestures of thought and writing that Michel Serres (who precedes Bruno Latour in this respect) makes in order to erase it and to establish knowledge on a (new) alliance between words and things ("les mots et les choses"). In the second and shortest part of this article, I seek to explain why Michel Serres's work has had very few echoes across the field of humanities until very recently. Finally, in a third and final step, I will try to demonstrate that his discursive refoundation relies on an ancient process whose mission was precisely to save from oblivion and update an early medieval hermeneutic technique deemed to be lost: the integumentum. As a process of relation, the medieval integumentum also poses the principle of the coalescence of the domains that modernity would so neatly distinguish: words and things, on the one hand, and fiction and theory, on the other.

\section{The historicity of discourses of knowledge}

In his aforementioned book, Michel Foucault shows how philology came into being, at the beginning of the nineteenth century, under the banner of the sciences of language (Foucault 1989, 305-329). If, for philology, the concept of the word is the result of a different kind of thinking from the one that presided over the general grammar that preceded it, it is now no longer the same concept. Hence, the object of eighteenthcentury grammar is no longer that of nineteenth-century philology, although in both cases we may use the same phrase: "sciences of language." 
However, it is not only a question of a new way of thinking and of a different object; style and rhetoric are also different, even if the awareness of this alteration is not immediately visible. Conceiving and describing new objects of knowledge leads to changes in the poetics of the respective discourse of knowledge.

The idea that the style of a discourse would change according to its object may nevertheless arouse the suspicions of a follower of Jacques Rancière's theory of aesthetic regimes who, in his book La Parole muette. Essais sur les contradictions de la littérature (1998 French ed., 2011 English ed., Mute Speech: Literature, Critical Theory, and Politics), argues precisely the opposite. In fact, Rancière identifies a break in the relationship between style and social rank in the name of the "propriety" of representation. The philosopher contrasts the discursive regime of "Belles lettres" with the "aesthetic" regime of modern literature. The author sets out four principles that define the first regime, including that of "decorum," which ensures that there is a correspondence between the social figures represented and the discourse they are supposed to hold (Rancière, Mute Speech 45). However, this principle was gradually overturned, roughly from the middle of the nineteenth century onwards: the principle of decorum (or of "appropriateness" - see Gabriel Rockhill, in Rancière, Mute Speech 12) was opposed by the indifference of style to the subject represented (Rancière, Mute Speech 50). Style is then no longer a mirror image, but a thick object which, at least before the advent of the avant-garde, reveals a surface that, while still making the representation of the world immediately intelligible, conceals a deeper and immediately unintelligible adequacy with the (social, historical) world.

However, Jacques Rancière hesitates to unpack all the consequences of his thesis. If style does indeed become indifferent to the objects represented according to a hierarchical order, while folding in on itself, it never ceases to incorporate a historicity that links it to the world. In other words, style never freezes, despite its halo of absoluteness which we perceive while reading for instance Mallarmé. The indifference posited by the French philosopher becomes, during the first half of the twentieth century, impassivity. Mixed with nominalism and skepticism, mainly after the setbacks of the Second World War, it became "white writing" for Barthes (Barthes, Le Degré zéro de l'écriture 173) - or "colourless" in English translation (Barthes, Writing Degree Zero 78). The style reverberates at the level of ethos and becomes indifferent to the very requirement of iconicity of representation. While one might be tempted to grant white writing the status of a literary eschaton, borrowing from 
Blanchot's literary eschatology, or to see in it the culmination of a Hegelian dialectic at the level of the universal truth requirement to which language must respond, Roland Barthes bitterly remarks at the end of Writing Degree Zero: "Unfortunately, nothing is more fickle than colourless writing; mechanical habits are developed in the very place where freedom existed, a network of set forms hem in more and more the pristine freshness of discourse, a mode of writing appears afresh in lieu of an indefinite language" (Barthes, Writing Degree Zero 78). The "aesthetic" regime of literature ends up changing its object, pace Jacques Rancière, who maintains that the dehierarchization of the order of representation leads to the reduction of the representational dimension itself. Style and object cannot be separated, but can only be articulated differently.

There is one more consequence to this mode of "epistemological break": if indifference becomes internalized, and the discourse itself ends up simply refusing to narrate, an explanation is needed forhow the object of this new discourse has changed. Modern literature gives up the scientific (and scientistisc) ambition to represent a world that literature used to not only describe as it is, but also arrange, as if it had prepared it for being properly described. It gives up mapping a world that science continues to penetrate ever more deeply, in order to find precisely what science does not say or cannot say. It is true that the objects represented in modern literature can no longer be classified from the point of view of classical "propriety," at least from the Avant-gardes onwards and as literature incorporates the voices of life forms that had not been previously given a voice (Gefen, L'idée de littérature 121-38). But colourless or white writing has also given rise to human figures that nineteenth-century realist literature did not know. Molloy, Malone (Beckett), Mersault (Camus) are just three characters who had no place in the mainstream realist novels of the nineteenth century. At an even lower level, that of the material objects represented, Samuel Beckett's objects - the pebbles in Molloy's pockets, for example - are not the same ones that interested Balzac. Even though the reader might find similar objects in both writers, their worlds are different.

The break that Jacques Rancière notes in Flaubert's novels (or in Victor Hugo's) as compared to the representative regime of the "Belles Lettres" is not only of heuristic value for the study of literary history. It does not only describe the "cultural" origin of modern literature and art. It is also symptomatic of a certain way of thinking, by separation. The regime of literary representation attributed to Belles Lettres did not 
cease to reproduce itself after the publication of Madame Bovary. The products made under this regime began to lose value, but they did not disappear, as a readership still existed for them. What they have lost is the place they had in an order of values constructed by literary criticism, by the discourses of the humanities which have been able to rise to prominence. They have been eliminated from the literary scene, but they live on, and it is only recently that literary criticism, at least in France, has taken an interest in them, precisely at the moment when, perhaps, the "modern" regime described by Jacques Rancière is in the process of tipping over (O. Bessard-Banquy, $\mathrm{S}$. Ducas, A. Gefen, Best-sellers. L'industrie du succès). The rupture - schism, secession, divorce, etc. - constitutes as such a model of intelligibility that seems to define modernity. In every bookshop there are shelves whose labels may change, but this internal variability is always presided over by the great binomial fiction/non-fiction.

Underhanded, this model of intelligibility is supported by oblivion. When Michel Foucault traces the genealogy of the human sciences in his aforementioned book, he implies that each new epistemic configuration erases the one it replaces: the face of modern man is not carved in stone with a diamond point, it is "a simple face drawn in sand at the edge of the sea" (Foucault 1989, 422). Ultimately, what interests Foucault is not the extinction of man, whose material reality he superbly ignores, as a good (post-)structuralist, but the disappearance of the configuration that made man possible as an object of thought.

In order to account for the split between words and things, or ideas and bodies, many authors go back to Descartes, for better or worse. Heidegger accuses Descartes of wrongly dividing being and states (Heidegger, Being and Time 42-47), and this was an ontological critique, as it aimed at the destitution of the primacy of being in relation to its constituents; Foucault himself relies, in Chapter III of The Order of Things, on the Cartesian opusculum Regulae ad directionem ingenii (Foucault 1989, 56-64), and his critique was political this time, as it aimed at the exclusion of the "madman" from the realm of reason that is supposed to define man's humanity. Now, to these two criticisms, which were conceived as theoretical positions that could easily be assigned to the "non-fiction" camp, a third criticism has been added for some time, which could be called ecological. It belongs to a philosopher in a class of his own, whose work collides with the discourse of French theory (even though Michel Foucault had been his student and later his colleague at Vincennes): Michel Serres. 
One of the cardinal issues of Michel Serres's work is that of ending the division of disciplines into two camps, the natural sciences and the human sciences, through what could be called a philosophical and stylistic anamnesis. To Deleuze's definition of philosophy - "philosophy is the art of forming, inventing, and fabricating concepts" (Deleuze and Guattari, What is Philosophy? 2) - Serres adds an element, the characters. "Because besides creating concepts, philosophy creates characters" (Michel Serres with Bruno Latour, Conversations on Science, Culture, and Time 74, French ed. Eclaircissements: cinq entretiens avec Bruno Latour, 1992, 112). Now, associating concepts and characters changes the deal: Hermes, the Parasite, the Hermaphrodite - all of them become philosophical references in the same way as the Deleuzian "body without organs" or the Heideggerian "Dasein." The lesson to be drawn from this adage is that through characters the two halves in which modernity had split the discourse of knowledge can communicate better than through concepts, since the latter are already instituted by virtue of the separation that precedes them. This embodiment of concepts has been increasingly practised ever since, so that it is now one of the main traits of the poetics of (post-)theory acknowledged on a global scale, including Romanian academia (see Laura Pavel, Characters of Theory, Beings of Fiction, 2021).

Michel Serres endeavours to render the complexity of knowledge beyond modern reductionism, notably in Le Passage du Nord-Ouest, the fifth volume of the Hermes cycle (Serres's Passage du Nord-Ouest). He does so already in the title, since the strait "which makes the Atlantic Ocean and the Pacific communicate" (Serres, Passage 15) is not only alluded to. A map including Alaska and the extreme tip of northeast Asia, linked by the Bering Strait opens the book. Serres confesses: "I am looking for the passage between exact science and the human sciences" (idem). It is in this context that Serres also goes back to Descartes, and perhaps it is by coincidence that he chooses as his anchor point the same early work of the French philosopher that Foucault studied, the Regulae (ca. 1628). For it was here that Descartes made his first conceptual segregation in the order of knowledge: "Descartes excludes the liquid, the fluid, by consideration of the edges, and the badly cut, badly sewn fabric of the imaginary composition, by the same consideration” (Serres, Passage 42). Michel Serres does not resort to Descartes' Regulae in order to restore dignity to madness, to the "madman" whose language finally makes sense, after Freud, but to make the Moderns aware of an enormous misunderstanding. On the one hand, the invention of 
science, which promised such a bright future, has not put an end to wars: "no fewer massacres have been committed in the learned Europe of the twentieth century than in the same places when they were covered with ancient forests" (Passage 127). On the other hand, the seizure of criticism over that of science throughout the twentieth century has in no way curbed ancestral violence. For "ideologies, theories, religions and sciences have always lulled us into hope as long as they fulfilled a critical function; they have always been atrocious when they have obtained power" (Passage 125).

It is no coincidence that Bruno Latour dedicates his first major work, The Pasteurization of France (English ed. 1988, French ed. 1984 Pasteur: Guerre et paix des microbes suivi de Irréductions), to "Michel Serres and to all those who are crossing the Northwest Passage." It is the first time that the author of We Have Never Been Modern attempts, within the rather restricted framework of the history of science from which he is trying to emancipate himself through this work, to undo the constitutive division between Subject and Object. Modernity has granted humans (as a matter of fact, man) the title of Subject because he is a dispenser of knowledge and a "logothete," while all the other beings and things became his Objects, objects of his knowledge and gestures. Latour does so within the supposed framework of an anthropology, according to a suggestion that Michel Serres makes explicit in Statues: "there is a history of science (...) but more profoundly there is an anthropology of it" (Michel Serres, Statues. The Second Book of Foundations 6). Bruno Latour reworks Serres's idea in The Pasteurization of France (62). The fact that science should be studied anthropologically is part of the same project of accounting for the contradictions of the Moderns, which Serres expresses very clearly in his Foreword to the second edition of The Natural Contract (French new edition 2018, Le Contrat Naturel 15-16): we live in a "a society which is completely transformed by the hard sciences but, on the other, which is directed by the soft sciences."

There is still another idea that Michel Serres and Bruno Latour share, and this is what I would like to focus on more: the need for a new style in order to build a new theory. This essay has just stated that any change in the style of a metalanguage triggers a change in its object and vice versa. It also showed that the object of Foucault's Order of Things and of Rancière's The Mute Speech was eventually the justification of a fundamental break in Western culture as the zero moment of Modernity. By the same token, in a way, Foucault and Rancière instituted their theories as radical metalanguages, the types of metalanguage seen as "horizon 
indepassable," as Sartre used to think of Kant, Hegel and Marx (Sartre, Critique de la raison dialectique 17). It is the very way to communicate knowledge that is no longer conceived as a consequence of the division between the humanities and the exact sciences. It also attempts to overcome the rhetorical division between fiction and nonfiction, to melt together language and metalanguage, but in another way than that of the "colourless language" so close to a pristine, sacred language. This is a big challenge, because it is not a question of accounting for a general indifference in the order of discourse, as Raymond Federman did in his well-known Critifiction. Postmodern Essays, where he wrote that "we are surrounded by discourses: historical, social, political, economic, medical, legal and, of course, literary. (...) We are made of discourses - words: spoken and written" (Federman, Critifiction 48, emphasis added by the author). On the contrary, Serres and Latour try to show, through a rhetorical renewal, that what is at stake now, in (post-)theory, is that "global history enters nature; global nature enters history: this is something utterly new in philosophy" (Serres, Natural Contract 4).

\section{Michel Serres, an early contemporary}

The aim of this essay is to follow the way in which Michel Serres is able to practise a different discourse from that of a "theory" that did not question one of its most obvious presuppositions, namely its belonging to the field of the "human" sciences - or even, as history has bequeathed us the label, to the "sciences of Man" (Richard Macksey and Eugenio Donato, The Structuralist Controversy 2007 [1970]). It goes without saying that the project of reconnecting human sciences and exact sciences has its origin in a common object that language hesitates to name (planet, nature, world, environment, ecology, etc.). At the same time, this is the origin of the attempt to trace the continuities between "archaic" and "modern" times calling for the refoundation of the discourse of knowledge (which we continue to call, by default, "theoretical"). Thus, the entire section on time from the 1992 dialogue between Bruno Latour and Michel Serres anticipates Giorgio Agamben's essay “What is the Contemporary?” (Giorgio Agamben, What is an Apparatus? and Other Essays 2009). "In order to say «contemporary», one must already be thinking of a certain time and thinking of it in a certain way" (Serres, Conversations 45). One of the criteria that Michel Serres uses in order to think contemporariness is the gap between "philosophical debate" and "scientific information" (Conversation 45). This is only the starting point of a perspective that 
allows unexpected relays for those trained either in the humanities or the hard sciences. Lucretius is the most frequent example in Serres's work, a philosopher from before the great epistemological bifurcation, someone whose work does not obey this modern division in the perimeter of knowledge. It is from the vantage point of the question of "the contemporary" that the refoundation of the discourse of knowledge is set in motion: "yet, without ceasing, we make archaic, modern and futuristic gestures at the same time", which refer to the "multitemporality" of any event in history (Serres, Conversations 60), but also, as we will soon see, to the very thought of the objects of the world.

The global recognition of Michel Serres's work is a recent phenomenon. He published a couple dozen books in the space of half a century, between 1968 and the year of his death, 2019, but they remained mostly unknown until recently. Christopher Watkins notes this in his recent book on the work of Michel Serres: "He does not appear in many lists of leading French philosophers or intellectuals, and less than half his work exists in English translation" (Christopher Watkin, Michel Serres. Figures of Thought 1). He goes on concluding: "In more ways than one, however, Serres is a thinker whose time has now come" (Watkin 2). Although he taught at Stanford University, like René Girard, at the same time as French Theory was rising in the United States, he has never been considered as one of its voices, except for the protagonists of the Sokal-Bricmont scandal who rank him among the "relativists", alongside Gilles Deleuze, Jacques Derrida and Jacques Lacan, but also Michel Foucault and Bruno Latour (François Cusset, French Theory 2). In François Cusset's history of French Theory, his name appears twice: the first time in a sentence quoted from Alain Sokal and Jean Bricmont's Impostures intellectuelles (Frech ed. 1997, English ed. Fashionable Nonsense: Postmodern Intellectuals' Abuse of Science, 1999), which we have just taken up, and towards the end of the book, to mention his position at Stanford. It is of little importance if it is through the prestige acquired by Bruno Latour's bilingual works (in French and English at about the same time) that the name of Michel Serres became influential in the West in the 2000 s in particular, contributing to the advent of an ecological thought several dimensions of which have become predominant today. They count in the first place the critique of modern thought that I have just alluded to in its Cartesian version, but also the critique of postmodernism as a critical discourse that forgets to consider its conditions of possibility: namely, the division between the exact sciences and the human sciences. 
A second essential dimension of what is known as "ecological thought" (Timothy Morton, The Ecological Thought, 2010) is the following: the critique of the primacy of "words" over "things." One of the unfortunate consequences resulting from the modern epistemological gesture of separation within metalanguage is the presupposition of the primacy of language over the real it is supposed to designate. Beyond realism and nominalism, ecological thought asserts that the thing - or the object, at this level "thing" and "object" are synonymous - precedes language. This is what Michel Serres states in his self-declared favourite book, Statues (Serres, Modelul lui Hermes [Hermes' Model] 60), where he relates the "statue" to the idea of a synthesis object overcoming the modern subject-object antithesis: "statues pass before languages and produce hominity first, before these languages refound it. Our ideas come to us from idols, language itself admits it; better, our ideas come back from them, like ghosts" (Serres, Statues 23). This is how an object - a nuclear rocket, an object of worship, a costume - can be studied in its multitemporality. This is one of the first images of the erasing of subject-object opposition as we acknowledge it today, embedded in the new ecological thought. Only later, in The Natural Contract, did Michel Serres consider it wiser to give a militant touch to his "North-Western strait" targeting mostly humanist "intellectuals" as you or me, in his way up to a mainstream theory.

It is, moreover, because of this campaign of exclusion, through epistemological division and political and ontological primacy, that Michel Serres's early works have been of little interest. Taking the Bering Strait instead of choosing between Asia and America means, in the first place, disorienting the reader, who no longer knows what kind of discourse he is reading. In fact, Michel Serres's discourse is not difficult because it is "poetic" (Watkin 154). To be sure, Serres "moves quickly from one bewildering array of ideas and subjects to another and floods the reader with a cataract of allusions and intertextual references" (Watkin 154), but what is disorienting is rather the fact that "the metalanguage comes always from the thing in question and not from the methodology used. It's a metalanguage imprisoned, crystallized or frozen within the very texts you use to make your explication" (Serres, Conversations 90).

This remark made by Bruno Latour during his conversations with Michel Serres already poses a problem of definition of the term metalanguage itself. For, according to his definition, metalanguage is that language used to explain another language: "when a speaker uses language not to speak about the world (others, etc.), but to speak 
about language (both written and spoken), he or she is said to be engaged in metalinguistic (or metalanguage) activity, that is, he or she constitutes language itself as an object of study or of discourse" (Yves Reuter, Cora Cohen-Azria, Bertrand Daunay, Isabelle Delcambre, Dominique Lahanier-Reuter, Dictionnaire des concepts fondamentaux des didactiques 123). What confuses the readers is that Michel Serres refuses to use metalanguage defined as such. He refuses to signal his text as a theoretical text, and he does so in the name of the obvious: "I avoid metalanguage because, more often than not, it also serves as an advertisement; what's the point of saying: I just did this or that? If you really do it, it's self-evident" (Serres, Conversations 91).

At the root of Michel Serres's work there is an intersectional vocation that may have confused his readers on more than one occasion. The rapid transition between Zola's novels and thermodynamics, for example, is shown to be due to the complexity of reality itself. There is a two-fold complexity, in space and in time. "Comparatism and the complexity of things and of time require swift movements? and a new style" (Serres, Conversation 72). At the same time, Michel Serres does not resort to fictional techniques to write his treatises, as Bruno Latour does, who puts his Inquiry into the Modes of Existence into a narrative (Bruno Latour, Inquiry into the Modes of Existence, 2013), devising as its main character a woman anthropologist who becomes his spokesperson, and knotting his plot all the way along the ethnological field of the "tribe" of Moderns. Indeed, Michel Serres does not invent any history in order to make his theoretical statements clearer; on the contrary, he quotes, paraphrases, and alludes to a number of literary texts without marking any apparent solution of continuity. He moves from one text to another back and forth, often without warning. He makes very little use of footnotes (unlike, for example, Derrida).

His syntax is mainly parataxis. Does he want to denounce how humans always overlook what lies above or underneath them, gods or objects? He begins to amass words detached by commas, as an example of the materiality of the mass at the origin of our cosmos of discreet things: "does society, the collectivity, drunk with noise, understand the object, subject or god, transcendent in relation to them, but that they - noisily - endlessly say they produced themselves?" (Serres, Statues 101). Parataxis exposes sentences to a simultaneous reading, more willingly exposed than chained, forcing us to look at all the words as objects arranged in a plain space ready to be perceived as a totality. For Serres, things - whose name comes from "cause," because 
in French they are called "choses" and are gathered together without any sense of ontological hierarchy - are originally free in a world whose description is distorted by argumentative syntax. Only syntax separates, breaks up, but it does not share. Things are, for a thought that unites words and things, causeless:

In every European language, in the north as well as in the south, the word chose [thing], whatever form it is given, has its origin or root in the word cause [case], derived from the judiciary, politics or critique in general. (...) Language claims that the world only comes from it. At least it says so. We sometimes feel that if the cases died awaymiracle-things as such would be born. The world shows things outside of any case, exonerated (Le monde montre les choses hors des causes) (Serres, Statues 59 [French ed. 1989, 111]).

The fact that the thing comes before language does not at all mean that the word comes always after the thing, but that the order of language is an a posteriori to the order of things. Throughout his work, Serres comes back to the reality of noise. All his 1980's Parasite is devoted to highlighting the importance of noise as a proper product of the parasite (no less than 399 instances of the word in Serres, The Parasite 1982). Noise is for words what mass is in regard to particular objects. Noises can be thought of as paratactic sounds, and this is maybe why Serres makes the choice of parataxis which, according to Graham Harman, better describes the reality of objects than "syntax" (in the sense of grammatical logic that slices and dices to offer an a posteriori meaning): "A more appropriate term than syntactic might be «paratactic», referring to the sideby-side existence of aesthetic elements rather than their mutual reference" (Harman, Art and objects 66). This choice can be interpreted as Serres's refusal of "theory" in favour of the simultaneous exposition of things: "I pile mountain upon mountain, Pelion upon Ossa, the Tower of Babel upon the Pyramid, the latter upon the mastabas, the Eiffel Tower upon the former, a road interchange or an interplanetary rocket upon the Eiffel Tower; I don't have the words or the theory, I don't have the pen to continue the series" (Serres, Statues 68). Parataxis, a kind of untied rhapsody, is the "irreduced" world, to speak with Latour (Latour, The Pasteurization 238), a world that is not rendered as a result of its conformation to the logic of the argument. Parataxis is also, as Christian Moraru writes about this same proposition by Graham Harman and, more generally, of object-oriented ontology in this very special issue of Metacritic, 
"paratactic logic that has the individual object's crisis flagging the systemic troubles of the bigger ensemble" (Moraru 2021, 22).

However, I think that this crisis is not so much that of the object in itself, but of the relations governing the position it occupies in time and space. Spatially, a paratactic position is no longer a matter of modern geometry, but of topology. From a temporal point of view, it is neither linear, nor cyclical. On the one hand, "classical time is related to geometry, having nothing to do with space, as Bergson pointed out all too briefly, but with metrics. (...) It's simply the difference between topology (the handkerchief is folded, crumpled, shredded) and geometry (the same fabric is ironed out)" (Serres, Conversations 60). Such a position, which is basically, to use a Serresian terminology that could undoubtedly be improved, "topological and multitemporal," is counter-intuitive for us as Moderns. It is invisible, but not because it is situated below, in depth in relation to a surface, but because it is here and there and it is then and now.

This ensemble is, for Serres, that of local and global networks actually, at the moment of each event that occurs locally and reverberates globally. It is not the description of the world according to the logic of the politics of war that best captures this, for this logic predicted that the American bombers Enola Gay and Bockscar would drop their bombs in order for WWII to end with the victory of those who possessed the bombers, whereas a paratactic description of the world could have predicted the effects of the bombing as they actually occurred in the completeness of their reality. Parataxis ensures that the history of the human world communicates with the history of the planet, and thus that historiography and geology work together and are part of the same dynamics.

\section{Ecology as integumentum. How to refound the discourse of knowledge}

The idea of an indebtedness of argumentative language to the reductive logic of the Moderns led to Serres's resorting to a different kind of language. It is at this point that he brings into play a rhetorical device that has been almost forgotten, since it is out of use in the discourse of theory: the integumentum (or involucrum: "wrapping"). As Denyse Delcourt notes in an article on the Lais of Marie de France, integumentum is a process that first leaves the truth in the shadows. Integumentum obscures truth in order to leave future readers the possibility of commenting on texts by adding what she still calls their "«surplus» of meaning” (Denyse Delcourt, "Oiseaux, ombre, désir: 
Écrire dans les Lais de Marie de France" 808). On the other hand, "integumentum is intended to play in the reading of pagan authors the role that allegory plays in the reading of the Bible" (Edouard Jeauneau, "L'Usage de la notion d'integumentum à travers les gloses de Guillaume de Conches" 37). It updates interpretation by means of what could be called an "adapting memory." Reading an integumentum means at the same time remembering what is supposed to be lost, and integrating it into reading through an update. Thus, a non-Christian/philosopher may well become a Christian one if the reader knows how to bring him up to date.

This term is so old that recent critics of Michel Serres's work no longer recognize it. Pierpaolo Antonello, a literary scholar interested in the work of our French philosopher writes about the linguistic complexity of Michel Serres's texts: "language encases knowledge; language is a historical palimpsest that needs to be unveiled and that traces the cultural and anthropological history of its formation" (quoted in Watkin, Michel Serres 156). Thus, Antonello unwittingly describes integumentum as a hermeneutic method that unearths truths embedded in a shell that is no longer current, but can be, and that prevents access, without naming it.

The twelfth-century Integumenta Ovidii by John of Garland may be the bestknown integumentum work of the Middle Ages which attempts to revive the literary works of pre-Christian antiquity. Fausto Ghisalberti, who published a critical edition of this work in Italian in 1933, writes by way of explanation: "The integumentum, which palliates and covers the occult truth with its veil of apparently guilty indulgence, is precisely what allowed the transmission and dissemination through the centuries of the good teaching of the Ancients"2 (H.J. Chaytor, "Integumenta Ovidii, by Giovanni di Garlandia, Fausto Ghisalberti” 76).

If integumentum rescues truths from oblivion caused by disuse, then the Serresian integumentum has a two-fold mission. On the one hand, it helps redesign some older, sometimes ancient texts in order to fit a new global ecological culture. This way, Serres's works are samples of what Yves Citton has called "actualization" in one of his most frequently quoted books, Lire, interpréter, actualiser: pourquoi les études littéraires? (Citton 2007). On the other hand, integumentum is not only a mnemonic device meant to update intellectual truths, but also something that reunites hard and

2 Latin original : "L'integumentum che pallia ed ammanta col suo velo di lenocini apparentemente peccaminosi la verità occulta, fu proprio quello che permise attraverso i secoli il tramandarsi e il diffondersi del buon ammaestramento degli antichi." 
soft sciences in a sort of "epistemodicy," as Serres puts it in the Natural Contract (26). Most of the texts that make up Michel Serres's literary bibliography have had little philosophical impact in the theoretical discourses that made up French theory; just yet, if some of them have aroused some interest (for example, the Balzacian short story Sarrasine for Barthes - Owen Heathcote, "Balzac and Theory, Balzac as Theory," 2009), the intertextual network that the French philosopher's texts coagulate remains alien to the intertextualities in vogue at the time of his writing. Serres is akin neither to psychoanalysis, nor to phenomenology, and if he often quotes the Heideggerian term "Dasein," he does so in order to show time and again how it eludes entirely the structure of the world which embeds it (Serres, Natural Contract 40-1).

The recourse to metalanguages that are specific to the objects dealing with them - in other words, the recourse to specific vocabularies - obscures the scope of Serresian discourse. The intended "truth," which is trans-historical, trans-epistemic, trans-generic and addresses world as a totality, calls for an ideal reader who should have a double training, as Bruno Latour has. However, this ideal reader is still difficult to find, as he or she should have been trained in both camps, that of the human sciences and that of the exact sciences; he or she should be an inhabitant of this uninhabitable "North-West strait." Serres's so-called "ensemblism" (Serres, Conversation 198) is properly ecological, according to the theoretical meaning that this term receives in Bruno Latour's Modes of existence (Latour, Modes 8), even though Michel Serres refuses to use this term, which for him designates a particular science3 (Serres, Le Contrat naturel 9). Christopher Watkin also uses the term "ecology" in his book dedicated to Serres's work. But if theory becomes ecology, like a Moebius strip, it is because its object - language as human and social language - is transforming. The most common name for this new object is Gaia (Frédérique AïtTouati, Emanuele Coccia, Le Cri de Gaia 2021), but it can also be the Earth or the planet, or even the World beyond subjects and objects. It might be what Jeffrey R. Di Leo and Christian Moraru had in mind when they undertook the grand project of coordinating a Handbook of World Theory (Di Leo, Moraru 2021). Michel Serres is well aware that, once the object of his thought becomes different from that envisaged by his colleagues whose work is classified as "French Theory," the whole language must

3 He mentioned during the discussions in Timișoara, in 2001: "If you read my Natural Contract more honestly than those who have criticized me on this point, there is never the word ecological mentioned in the book" (Serres, Hermes' Model 54). 
change. In the first place, what has to change is the relationship between the discourse of knowledge that is enunciated by the so-called subject of knowledge, the author himself, and its alleged object. Now, another reversal is taking place: the author is no longer completely in control of his discourse, not because he would have "died" before the multitude of receivers who can use the text as they please, but because he is not the transcendent source of an argumentative rhetoric that unfolds vertically. He is the one who renders as he perceives the "heap" of things from his totalizing and yet incomplete perspective, which brings together numbers and letters, sentences and formulas, concepts and characters, words and objects - the things of the world. This simultaneous distribution, however, is not a rhapsody, it offers itself to be unveiled, while calling for a reading different from those supposed by an argumentative text.

The reader accustomed to recognizing and unveiling integumenta is not a modern reader. He/she knows whether he/she is reading "fiction" or "non-fiction," or maybe "psychology" or "self-development." The reader is generally sufficiently knowledgeable to know whether what he/she is reading belongs to the exact sciences or to the humanities, even if he/she may have doubts about the discipline from which a particular text comes. To understand an integumentum, the reader has to go beyond the modern division between fiction and non-fiction, beyond the "fictional pact" that relies on the "suspension of disbelief" theorized at the beginning of the Romantic period (Samuel Taylor Coleridge, Biographia Litteraria [1817] ch. XIV https://web.english.upenn.edu/ mgamer/Etexts/biographia.html), to a time difficult to identify in its own historicity. Michel Serres's texts belong, like many texts from Latin antiquity, the Middle Ages and through the Western Renaissance, to an idea of "literature" that predates the divisions made explicit by Michel Foucault and Jacques Rancière, in which two different orders of discourse are conceived with the latter "forgetting" the former which thus becomes unreadable.

How does one read an integumentum? Jeaneau finds that the first means needed to reveal the truth hidden under the flattering clothes of poetic rhetoric is etymology, the practice of which is essential for all of Michel Serres's texts. In this respect, The Parasite is one of the best illustrations of etymological embededness (Serres, The Parasite 155). Here, Serres breaks down the word into "para-site," someone who is situated away from, in addition to, and alongside a place, a "site." The parasite is a kind of "para-place". If, in the Middle Ages, the person who resorted to etymology was the commentator, the glossator of an ancient text - since reading 
presupposed leaving the present for a past that retained, preserved its truth - , in Michel Serres's case the reference text and his own text become entangled. He is a commentator, as well as an author, which makes him less than an "author" in the modern sense of the term - the subject of an object that belongs to him - and more than a commentator, because the contemporary pasts of the texts on which he relies are made present only through his own text. There is no (more) truth without technology updating it. Michel Serres's use of integumentum poses additional problems, since he writes in the twentieth century, and this is not a procedure that he seems to have taken up consciously. Although he is widely read in classical French literature - from Montaigne to Rousseau and Balzac - and ancient literature - notably Lucretius -, Michel Serres does not pay particular attention to medieval commentary as such. He consistently describes his own style in terms that reflect his project to straddle the two scientific camps, the humanities and the hard sciences.

Basically, the meaning of the integumentum lies perhaps in the preposition: inter, in, in-between. In Serres's works, the preposition may reveal itself as a heuristic tool proper to decipher integumentum, situating what is to be understood between the "object" and its "envelope":

Now let's forget content - science, literature, anthropology, even the content of philosophy. There are simply bodies of texts, situations, places, objects. Fewer and fewer texts, too, and more and more objects. Let's try to forget that there are distinct disciplines - literature, the arts, etc. Let's try to see that the mode of moving from place to place is the scientific mode. Science is not a content but, rather, a means of getting about (Serres, Conversation 103-4).

The key preposition here isn't "about," and maybe one has to acknowledge the importance of prepositions for a thinker whose native language is not English, but French. In English, prepositions very often accompany verbs, while in French prepositions acquire a relational value which they do not have in non-Latin languages. The key preposition here is "between," as the French original of "getting about" is "circulation" (Serres, Eclaircissements 154). Latour makes wide use of prepositions as a concept in his Modes of Existence, so that prepositions become a sort of logo of the book (he designates all sixteen modes of existence according to an acronym formed by the first three letters of each of their names, as these letters had preceded the name 
itself). Like the parasite, the preposition is a term which designates places, lieux: "Prepositions - what better name for those relations that precede any position?” (Serres, Conversations 105).

Indeed, "between" is the preposition that becomes the key to reading Serres's ecology: "between has always struck me as a preposition of prime importance" (Serres, Conversations 64). And further on: "The space between - that of conjunctions, the interdisciplinary ground - is still very much unexplored. One must travel quickly when the thing to be thought about is complex" (Conversations 70). Michel Serres states that he is transporting a metalanguage, "algebraic or topological" (idem), originating in mathematics, into the realm of theoretical (humanist) discourse (Conversations 71). Now, what lies between is the skin, the tegmen, that thing which covers. The tegmen is the "between" that connects what is true and lasting under the skin that changes and lies above. We always forget what stands underneath, because we only see this skin. Exposed to the energy of the integumentum once it is revealed, that truth becomes updated inasmuch as it is re-tied and re-linked to us. In French, this can be put as wordplay: "nouer" means to tie, to link, while "nous" means "we" (Marielle Macé, Nos cabanes, 2019, 22).

The integumentum does not only presuppose an intertextuality that alleges references without marking them with inverted commas or footnotes. It also acts, and more profoundly, at the level of the organization of the discourse which sometimes takes on the appearance, to quote Michel Serres again, of the "flight of the fly" (Serres, Conversations 65), of a relationship between both sides of what is visible, below and beyond the tegmen, unpredictable and dynamic: "follow the flight pattern of a fly. Doesn't time sometimes flow according to the breaks and bends that this flight seems to follow or invent?" (Conversations 64-5).

Integumentum is also the form of the contemporariness as Michel Serres defines it: multitemporal, where temporalities are articulated through a dialectic that makes events or texts from the past give birth to possible readings that the present alone is not prepared to produce. Thus, integumentum becomes the expression of a break: it breaks the modern decision of the separation that founds it, between a nature conceived as a resource and a humanity as a huge being consuming it. Integumentum discloses not only a memory process, making multitemporality perceptible, but also the poietic clutch of a discourse that is enunciated (and of a text that is written) beyond the division that founds European written culture, between argument/fiction. It is in 
this sense that Bruno Latour's remark on the "Serres test" should be understood: "the Serres test: does the past, supposedly irrational, rather than resisting historical reconstitution, find itself as solid as the newest and most contemporary rationality?" (Latour, in Serres, Conversations 62).

This dialectic aims neither at transcendence, nor at an Aufhebung that eliminates the "individual" in favour of the "general." The dialectic draped by the integumentum is rather of a biological order and is in some ways a matter of life sciences. It brings the subject out of the object, and the object out of the subject, over and over again, as if the two were but the two faces of a Janus. This dialectic is only possible because subject and object do not belong to an "ontological reality" but to a semiotic pragmatics, as Frédérique Aït-Touati and Emanuele Coccia eloquently assert in the opening of their book (Le Cri de Gaïa 10).

The best example of a Serresian integumentum can be found in his book Statues. We remark at once that the author chooses to use the plural of the noun, while in The Parasite he uses the singular. There are many "statues" in this world, but only one "parasite" (only humans are truly parasites). Serres begins with an account of the Challenger rocket disaster on 28 January 1986 (shortly before the Chernobyl explosion, in fact), which he compares to the cult of Baal, that bizarre god represented by an enormous statue, "lord of the flies" (Serres, Statues 3), for whose favours the Carthaginians are said to have made human sacrifices up to the fourth century. The respective statue was equipped with compartments, one of which was intended to receive sacrificial children. What is the connection between a rocket that explodes at the end of the twentieth century and a three-dimensional representation of a god whose cult gradually dies out at the beginning of the Christian era? The temporal integumentum is quickly revealed: these are two products of the same technique albeit of two distinctly different "epistemê" - through which an object is constructed in order to bring death: "immobile at first, the statue moves and leaves. But the idol or the rocket are tombs. End of the dictionary in the black box" (Statues 4). After a first analogy between two superhuman objects built to house humans, a second analogy between the two objects is intended, this time addressing the purpose for which the two constructions are carried out: the spaceship which exploded killed all those inside, while the statue erected in honour of Baal became the tomb of children "who were believed to be the first-born of the rich and noble families" (Statues 3). A third analogy is unpacked: in both cases, the death of the victims is accepted as an accident. The 
crash of Challenger is an accident for us, the Moderns, while the crowd gathered to watch the spectacle of the cult of Baal referred to the sacrificed children as "oxen," not human beings (idem).

Both the rocket and the statue containing human beings doomed to death are "statues." The two facts, the event and the legend are both retained by history. But then they are repartitioned in two stories which modern knowledge separates through two exclusions that forever forbid that 1 (rocket) +1 (statue) $=2$. Serres does not intend to reunite them by means of a metalanguage that would reduce each to moments in an argumentation. Serres refuses this way of constructing a theoretical, argumentative text. He only juxtaposes stories (the story of Challenger, the story of Baal, and so on). Here, paratax replaces syntax. What is, then, a statue for Michel Serres? Something for the construction of which inanimate objects and beings are taken from the world in order to make the former move and the latter become inert. The statue is therefore something that brings death - then and now - according to a "fetishist" technology in the past, a "scientific" one today ("scientific" according to present day vocabulary), in front of the same crowd fascinated by the spectacle of death, in "presence" then, at a "distance" now. The two ages resemble each other, there is then a "contemporaneity" between the two events, according to the definition given by the author: "the word contemporary automatically takes two contradictory meanings: it means that Lucretius, in his own time, really was already thinking in terms of flux, turbulence and chaos, and, secondly, that through this, he is part of our era, which is rethinking similar problems" (Serres, Conversations 47, italics by the author).

Recourse to Jules Verne will allow Michel Serres to further unpack his own integumentum: statues are not only objects endowed with purposes as those mentioned above, they are also objects that sow confusion between what we commonly understand as objects and subjects. This time, Serres takes a scene from Verne's novel Around the Moon (1865), the novel by Verne that follows the better known From the Earth to the Moon (1869). It is about a flight in space imagined by Verne, aboard a bomb propelled by a cannon named the Columbiad. The bomb replaces the spaceship. That is what Verne imagined a century before the Moon was reached by man not in a bomb, but in a rocket. Aboard this bomb there was also a dog that, Verne tells us, came to die in weightlessness. At that moment, as it was impossible to keep the corpse aboard, the crew decided to get rid of it, and the dog was thrown through a trapdoor into space (however counter-intuitive this gesture appears to us today). Alone in 
interstellar space, in zero gravity, the dog's corpse does not "fall;" it begins to accompany the rocket closely, like a satellite. This is the moment when this dog acquires, in Serres's work, a double value: firstly, it is the "thought unthought" of progress, the repressed that returns, the corpse of a "primitive" world, which the crew that embodies modern society wisely wanted to get rid of. But even more profoundly, this dog is a subject (when it is alive) that has become an object through death and the expulsion that has been inflicted on it: "the phantom, the object, that," "a thing was progressing behind progress" (Serres, Statues 16).

The following chapters of Statues, whose order is chronological and regressive, only provide further evidence, through other stories, i.e., other characters, of the subject-object instability of every thing in the world, and of the ignorance in which we find ourselves when it comes to understanding the separation between subject and object.

The collectivity knows only itself and gives itself only itself as object, its noise, its relations, its streets and its swamp, its glory, its power, its politics, its hatreds. The collectivity is fed by and makes its clamours its delights, deaf to the noises of the world, blind to its light, insensible to its calls. And suddenly a terrible din dominates the croaking; the aerolith, via gravity, is falling from the skies. Then the collectivity recognizes, for a moment, the existence of another world (Serres, Statues 101).

Integumentum acquires a heuristic value that Serres's contemporaries were (are?) maybe ill-equipped to discover. For what his texts convey, and Statues in particular the beginning of a discourse that, in the 2000s, finally becomes clear - is that Gaïa, the Earth, is a subject-object, precisely what Bruno Latour set out to demonstrate in his Inquiry into the Modes of Existence. But what has now become an irrefutable argument, that subjects and objects are only topological positions and moments embedded in multitemporality, was not, for Michel Serres, an argument. Acknowledging the idea that integumentum may become an argument in the same manner in which objects used to be subjects and vice-versa is in a way acknowledging that the argument is not necessarily the language of reason, but a language which increasingly acquired force, up to a climax where force became reason. As reason, "rationality," force lets us see its modern allure, something like a natural light. Yet, 
reason is nothing but a skin, a get-up of a force (truth, objectivity, "in-itself") in the same manner that Challenger is nothing but the latest form of a statue.

We are today thinkers and writers of arguments. Only they are reasonable, only they can be authoritative and only they tell the truth. Yet, we have to come back to Michel Serres each time we want to recover the properly eco-logical historicity of the discourse "between," of the "passage of the Northwest," in order to experience and understand our world - Gaïa, the planet, life - beyond argument.

\section{Coda}

The reader may well look down on this conclusion, which insists on the ecological virtues of the integumentum, as a retrograde position. He will be right to object that it is impossible, nowadays, to return to the integumentum in theoretical writing, while at the same time chasing away the argumentative rhetoric that is the foundation of our discursive modernity. If it is true that Michel Serres deliberately deviates from "theory," we have to admit that the singularity of his texts, which is less and less marked from the Natural Contract onwards, is not and cannot become a writing model for "ecological" scholarship. Scientific journals have long since imposed a writing model that has become a veritable genre, and there are still few that do without it (there are some, for example https://scholars.wlu.ca/thegoose/).

Indeed, it is not a question of a return to the integumentum that we are advocating here, but of the possibility of drawing, in our own writing, certain features or traits of Michel Serres's writing. At the heart of our advocacy is an idea put forward by Vinciane Despret in a discussion about the reintroduction of mammoths into the Siberian tundra and the effects that such a de-extinction would have on the ecosystem in question (Despret 2021, 127-141). Such an operation would be dangerous, as it would destroy an ecological balance that has been carefully achieved since the disappearance of these prehistoric animals, the last representatives of which are thought to have gone extinct at the beginning of the second millennium BC. In the words of the philosopher, "it is not a question of resurrection of species, but of ecological resurrection" (Despret 2021, 135). The key term here is trait. It appears in Latour's Facing Gaïa (Latour 2017), and had already appeared in Serres's etymology of the words "contract" and "attraction," with the meaning of "link," something that makes two individual existences symbiotic: "The great planetary bodies grasp or comprehend one another and are bound by a law, to be sure, but a law that is the 
spitting image of a contract, in the primary meaning of a set of cords" (Serres 1995b, 108). The trait is thus what links an individual to others; it can be thought of as an affordance, and a being can then be conceived, in a non-essentialist way, as a bundle of traits whose dynamic node is in a ceaseless process of change, certainly on a planetary time scale.

If the writing of Michel Serres, at least before the 1990s, refuses argumentation in favour of strings of analogies, collections of exempla, and the practice of integumentum, it is not necessary to leave the generalized and institutionalized practice of argumentative discourse as an "ecological" attestation. It is enough to borrow certain features: the use of fictional categories (characters, narrations, dramatizations), the use of all kinds of representations (theatre for Frédérique AïtTouati, the exhibition for Bruno Latour), the exploitation of generic interstices (which could be grouped together under the name of the essay), and even the occasional use of the integumentum are all rhetorical procedures with an ecological value insofar as they (con)consciously circulate discursive features. This is also how we can work together to define an ecological memory, which would not be understood as the mental retention of snippets of different pasts brought together by the idea of a self and undergoing a process of affective deformation related to this same self, but the constitution of a reservoir of designs of existence that overflows the individualizing principle presiding over affective memory. The reminder of the integumentum as a discursive design will have been modest proof of this.

\section{References}

Aït-Touati, Frédérique, and Emanuele Coccia. Le Cri de Gaia. Paris: La Découverte, 2021.

Barthes, Roland. Le Degré Zéro de l'écriture, dans Euvres complètes I. Paris: Seuil, 2002. [Writing Degree Zero, translated by Annette Lavers and Colin Smith. London: Jonathan Cape, 1967].

H. J. Chaytor. "Integumenta Ovidii, by Giovanni di Garlandia, Fausto Ghisalberti." Medium Avum 3. 1 (1934): 75-6.

Cusset, François. French Theory: How Foucault, Derrida, Deleuze \& Co. transformed the Intellectual Life of the United States. University of Minnesota Press, 2008. Translated by Jeff Fort. 
Delcourt, Denyse. “Oiseaux, ombre, désir: Écrire dans les Lais de Marie de France," MLN 120/4 (September 2005): 807-24.

Deleuze, Gilles and Félix Guattari. What is Philosophy? New York: Columbia University Press, 1994. Translated by Hugh Tomlinson and Graham Burchell.

Despret, Vinciane. “Comment accueillir les mammouths?” Le Cri de Gaia. Ed. AïtTouati, et al. Paris, La Découverte, 2021: 127-41.

Di Leo, Jeffrey R and Christian Moraru. The Bloomsbury Handbook of World Theory. Bloomsbury, 2021.

Foucault, Michel. The Order of Things. An Archeology of Human Sciences. London: Routledge, 1989.

Gefen, Alexandre. L'Idée de littérature. De l'art pour l'art aux écritures d’interventions. Paris: Corti, 2021.

Heidegger, Martin. Being and Time. New York, SUNY Press, 1996. Translated by Joan Stambaugh.

Gheorghiu, Mihai Dinu. Scena literaturii, Elemente pentru o sociologie a culturii românești [The Stage of Literature. Elements for a Sociology of Romanian Culture]. Bucharest: Minerva, 1987.

Jeauneau, Edouard. "L'Usage de la notion d'integumentum à travers les gloses de Guillaume de Conches" in Archives d'histoire doctrinale et littéraire du Moyen Age, Vol. 24 (1957): 35-100.

Latour, Bruno. The Pasteurization of France. Harvard University Press, 1988. Translated by Alan Sheridan and John Law.

---. Inquiry into the Modes of Existence. An Anthropology of the Moderns. Harvard University Press, 2013. Translated by Catherine Porter.

---. Facing Gaia. Eight Lectures on the New Climatic Regime. Polity Press, 2017. Translated by Catherine Porter.

Macé, Marielle. Nos Cabanes. Paris: Verdier, 2019.

Moraru, Christian. "Objecthood, Flat Form, Political Formalism: OOO and Ben Lerner's Hatred of Poetry." Metacritic Journal for Comparative Studies and Theory 7.1, (2021): 16-39.

Pavel, Laura. Personaje ale teoriei, ființe ale ficțiunii [Characters of theory, beings of fiction]. Iași: Institutul European, 2021. 
Rancière, Jacques. Mute Speech: Literature, Critical Theory, and Politics. Columbia University Press, 2011. Translated by James Swenson. Introduction by Gabriel Rockhill.

Reuter, Yves, et al. Dictionnaire des concepts fondamentaux des didactiques. Louvain-la-Neuve: De Boeck Supérieur, 2013.

Serres, Michel with Bruno Latour. Conversations on Science, Culture, and Time. Translated by Roxanne Lapidus. University of Michigan Press, 1995.

---. Hermès V. Le Passage du Nord-Ouest. Paris: Minuit, 1980.

---. The Parasite. Translated by Lawrence R. Schehr. Baltimore: John Hopkins University Press, 1982.

---. The Natural Contract. Translated by Elizabeth MacArthur and William Paulson Ann. University of Michigan Press, 1995b.

---. Modelul lui Hermes [Hermes' Model]. Timişoara: Editura Universităţii de Vest, 2003.

---. Le Contrat naturel (new edition). Paris: Le Pommier, 2018.

---. Statues. The Second Book of Foundations. London: Bloomsbury, 2015. Translated by Randolph Burks.

Watkin, Christopher. Michel Serres. Figures of Thought. Edinburgh University Press, 2020. 